\title{
PERTUMBUHAN DAN HASIL RUMPUT Setaria splendida Stapf YANG DIPUPUK DENGAN PUPUK KOTORAN SAPI DAN BIOURIN DENGAN DOSIS BERBEDA
}

\author{
M. Nuzulus Sifa', A. A. A. Sri Trisnadewi, dan I Ketut Mangku Budiasa \\ Program Studi Sarjana Peternakan, Fakultas Peternakan, Universitas Udayana \\ e-mail: nuzulussifaa@gmail.com
}

\begin{abstract}
ABSTRAK
Penelitian bertujuan untuk mengetahui dan memberikan informasi mengenai pertumbuhan dan produksi rumput Setaria splendida Stapf yang dipupuk dengan pupuk kotoran sapi dan biourin dengan dosis berbeda. Penelitian dilakukan di Rumah Kaca, Stasiun Penelitian Sesetan, Fakultas Peternakan, Universitas Udayana di Jalan Raya Sesetan Gang Markisa Denpasar. Penelitian berlangsung selama 10 minggu, menggunakan rancangan acak lengkap (RAL) pola faktorial. Faktor pertama adalah pemberian pupuk kotoran sapi dengan dosis o ton ha ${ }^{-1}$ (So), 15 ton ha ${ }^{-1}(\mathrm{~S} 1), 30$ ton $\mathrm{ha}^{-1}(\mathrm{~S} 2)$ dan faktor kedua adalah pemberian biourin dengan dosis o l/ha (Uo), $25001 \mathrm{ha}^{-1}(\mathrm{U} 1), 50001 \mathrm{ha}^{-1}(\mathrm{U} 2), 75001 \mathrm{ha}^{-1}\left(\mathrm{U}_{3}\right)$. Setiap perlakuan diulang sebanyak tiga kali sehingga terdapat 36 unit percobaan. Variabel yang diamati yaitu pertumbuhan, produksi dan karakteristik tumbuh rumput. Hasil penelitian menunjukkan pemberian pupuk kotoran sapi pada dosis 15 ton $\mathrm{ha}^{-1}$ memberikan pengaruh terbaik pada variabel jumlah daun dan anakan serta hasil rumput Setaria splendida Stapf. Pemberian pupuk biourin tidak memberikan pengaruh yang nyata terhadap semua variabel pertumbuhan dan hasil rumput. Tidak ada interaksi antara pemberian pupuk kotoran sapi dan biourin. Kesimpulan hasil penelitian adalah rumput Setaria splendida yang diberi pupuk kotoran sapi dengan dosis 15 ton ha ${ }^{-1}$ memberikan pertumbuhan dan hasil terbaik, pemberian pupuk biourin sampai dosis $75001 \mathrm{ha}^{-1}$ tidak berpengaruh terhadap pertumbuhan dan hasil rumput Setaria splendida Stapf.
\end{abstract}

Kata kunci: pertumbuhan, produksi, rumput Setaria splendida Stapf, pupuk kotoran sapi, biourin

\section{GROWTH AND YIELD OF SETARIA SPLENDIDA STAPF GRASS FERTILIZED WITH VAROUS LEVEL OF COW MANURE AND BIOURIN FERTILIZER}

\begin{abstract}
This study aims to determine and provide information about the growth and results of Setaria splendida Stapf grass which was fertilized with cow manure fertilizer and biourin with different dosages. The study was conducted at the Greenhouse, Sesetan Research Station, Faculty of Animal Husbandry, Udayana University in Jalan Raya Sesetan Gang Markisa Denpasar. The study was conducted for 10 weeks, using completely randomize design (CRD) with factorial pattern. The first factor was dosage of cow manure o ton ha-1 (So), 15 ton/ ha (S1), 30 tons/ha (S2) and the second factor was the application of biourin at a dose of o l/ha (Uo), $2500 \mathrm{l} \mathrm{ha}^{-1}$ (U1), $5000 \mathrm{l} \mathrm{ha}^{-1}$ (U2), $7500 \mathrm{l} \mathrm{ha}^{-1}$ (U3). Each treatment was repeated three times so that there were 36 unit trials experiment. The variables observed were growth, results and growth characteristic of grass. Results of the study showed that cow manure with dosage 15 tons ha ${ }^{-1}$ gave the significant effect on leaf and tiller amount and yield of Setaria splendida Stapf grass. The application of biourine fertilizer had no significant effect on growth and yield of Setaria splendida Stapf grass. There was no interaction between cow manure and biourine fertilizer. Conclusion of the experiment that Setaria splendida Stapf which given cow manure fertilizer on dose of 15 tons ha ${ }^{-1}$ gave the best on growth and results, and no effect with biourin fertilizer until the dosage of $7500 \mathrm{l} \mathrm{ha}^{-1}$ has no effect on the growth and yield of Setaria Splendida Stapf grass.
\end{abstract}

Keywords: growth, yield, Setaria splendida Stapf grass, cow manure, biourine 


\section{PENDAHULUAN}

Keberhasilan dalam suatu usaha peternakan sangat didukung oleh persediaan bibit, manajemen yang baik dan persediaan pakan yang memadai. Pakan adalah salah satu faktor yang sangat menentukan berhasil tidaknya usaha peternakan. Usaha meningkatkan hasil peternakan sangat didukung oleh tersedianya bahan pakan terutama hijauan yang berkualiatas dan tersedia sepanjang tahun, sehingga perlu diupayakan pengembangan hijuan pakan secara berkesinambungan.

Susetyo et al. (1980) menyatakan bahwa hijauan pakan mempunyai peranan penting bagi ternak ruminansia dan merupakan pakan utama sebagai sumber gizi yaitu protein, energi, vitamin dan mineral. Hijauan pakan ternak terdiri dari rumput, legum dan daun pohon. Rumput Setaria splendida Stapf merupakan jenis rumput mempunyai sifat-sifat yang baik sebagai tanaman pakan baik dari adaptasi, kompatabilitas, hasil dan kualitas hijauannya (McIlroy, 1976). Rumput Setaria splendida Stapf sesuai untuk daerah tropik lembab, tumbuh membentuk rumpun lebat dan kuat, tumbuh baik pada ketinggian 1000 - $3000 \mathrm{~m}$ di atas permukaan laut, tahan naungan dan genangan, tinggi mencapai $1,5 \mathrm{~m}$, dan hasilnya berkisar antara $60-100$ ton ha ${ }^{-1}$ tahun $^{-1}$. Rumput Setaria splendida Stapf sangat cocok ditanam di tanah yang mempunyai ketinggian $1200 \mathrm{~m}$ di atas permukaan air laut, dengan curah hujan tahunan $750 \mathrm{~mm}$ atau lebih, dapat tumbuh di berbagai jenis tanah, dan tahan terhadap genangan air.

Untuk meningkatkan pertumbuhan dan hasil rumput Setaria splendida Stapf maka perlu ditunjang dengan ketersediaan unsur hara yaitu dengan cara pemupukan. Pemberian pupuk pada tanaman dapat dilakukan dengan menggunakan pupuk organik maupun anorganik (Indranada, 1985).

Pupuk organik adalah pupuk yang sebagian atau seluruhnya terdiri dari bahan organik yang berasal dari tanaman atau hewan, dapat berbentuk padat atau cair yang digunakan untuk mensuplai bahan organik untuk memperbaiki sifat fisik, kimia, dan biologi tanah (Suriadikarta dan Simanungkalit, 2006). Sumber pupuk organik salah satunya berupa pupuk kotoran sapi dan biourin. Arnawa (2014) menyatakan bahwa penggunaan pupuk organik kotoran sapi, kotoran kambing dan limbah biogas pada level 1030 ton ha ${ }^{-1}$ meningkatkan pertumbuhan dan hasil rumput benggala.

Biourin merupakan salah satu pupuk organik yang cocok untuk alam tropis dan juga baik untuk tanaman keras maupun lunak karena tidak meninggalkan residu di dalam tanah dan membuat tanah menjadi gembur. Penggunaan biourin dapat memperbaiki tekstur tanah, biologi tanah dan dapat meningkatkan hasil tanaman (Nurhajati et al., 1986). Semakin tinggi dosis pemupukan biourin (25.000 $\mathrm{ha}^{-1}, 50.000 \mathrm{l} \mathrm{ha}^{-1}$, $75.000 \mathrm{l} \mathrm{ha}^{-1}$ ) mengakibatkan pertumbuhan tanaman meningkat karena unsur hara yang terkandung pada tanaman juga tinggi (Nuriyasa et al., 2014).

Hasil penelitian Adijaya (2009) didapatkan bahwa pemberian urin sapi dengan dosis $7500 \mathrm{l} / \mathrm{ha}$ mampu meningkatkan biomassa rumput raja sebesar 90,18\% dibanding tanpa pemupukan dan berbeda tidak nyata pada pengamatan biomassa rumput raja yang diberi urea sebanyak $250 \mathrm{~kg} \mathrm{ha}^{-1}$. Selain itu, hasil penelitian Nuriyasa et al. (2012) menunjukkan bahwa pemberian pupuk biourin dengan dosis 75000 1 ha $^{-1}$ menghasilkan tinggi tanaman, jumlah daun dan anakan lebih tinggi daripada dosis $50000 \mathrm{l} / \mathrm{ha}$, 250001 ha $^{-1}$ dan tanpa pemupukan biourin.

Berdasarkan permasalahan diatas maka perlu dilakukan penelitian mengenai pertumbuhan dan hasil rumput Setaria splendida Stapf yang dipupuk dengan pupuk organik padat disertai penambahan biourin dengan dosis berbeda.

\section{MATERI DAN METODE}

Percobaan dilakukan di Rumah Kaca Stasiun Penelitian Sesetan Fakultas Peternakan Universitas Udayana. Bibit Rumput yang digunakan adalah jenis Rumput Setaria splendida Stapf. Tanah yang digunakan diambil dari di lokasi Stasiun Penelitian Fakultas Peternakan, Desa Pengotan, Kabupaten Bangli, yang memiliki tekstur pasir berlempung dengan kandungan $\mathrm{C}$ organik 1,22\% (rendah), $\mathrm{N}$ total $0,13 \%$ (rendah), P tersedia 45,43 ppm (sangat tinggi), kadar air kering udara (Ku) 4,07\% dan kapasitas lapang 30,52\%. Tanah yang akan dipakai terlebih dahulu dikering udarakan, kemudian ditumbuk halus, selanjutnya diayak dengan tujuan agar ukuran partikel tanah merata. Tanah ditimbang dan dimasukkan ke dalam pot yang masing-masing diisi sebanyak $4 \mathrm{~kg}$ tanah kering udara. Tanah dalam pot kemudian disiram dengan air sampai kapasitas lapang. Percobaan menggunakan pot berbahan dasar plastik yang berdiameter $26 \mathrm{~cm}$ dan tinggi $19 \mathrm{~cm}$ sebanyak 36 buah. Pupuk yang digunakan yaitu pupuk kotoran sapi yang berasal dari feses sapi dan biourin yang diberasal dari urin sapi. Analisa kandungan unsur hara dilakukan di Laboratorium Biosain Politeknik Negeri Jember. Pupuk kotoran sapi mengandung unsur $\mathrm{N}(1,699 \%), \mathrm{P}_{2} \mathrm{O} 5$ (1,654\%), $\mathrm{K}_{2} \mathrm{O}(4,603 \%)$ dan C-organik (24,494\%), sedangkan biourin mengandung unsur $\mathrm{N}(1,2 \%), \mathrm{P}_{2} \mathrm{O} 5(0,58 \%), \mathrm{K}$ (o,73\%), dan C-organik (2,67\%). Rancangan percobaan yang dipergunakan adalah rancangan acak lengkap (RAL) pola faktorial. Faktor pertama yaitu pupuk 
kotoran sapi (S) dengan dosis o ton/h, 15 ton ha ${ }^{-1}$, 30 ton $\mathrm{ha}^{-1}$ dan faktor kedua yaitu biourin dengan dosis o l ha-1, $25001 \mathrm{ha}^{-1}$, $5000 \mathrm{l} \mathrm{ha} \mathrm{h}^{-1}$, $7500 \mathrm{l} \mathrm{ha}{ }^{-1}$. Kombinasi perlakuan diulang tiga kali, sehingga pot yang digunakan adalah 36 pot. Peubah yang meliputi: tinggi tanaman, jumlah daun, jumlah batang, berat kering daun, berat kering batang, berat kering total hijauan, berat kering akar, nisbah berat kering daun dengan berat kering batang dan nisbah berat kering total hijauan dengan berat kering akar.

\section{HASIL DAN PEMBAHASAN}

\section{Pupuk Kotoran Sapi}

Hasil penelitian rumput Setaria splendida Stapf menunjukkan pada pemberian pupuk kotoran sapi pada variabel jumlah daun dan jumlah anakan secara statistik menunjukkan berbeda nyata $(\mathrm{P}<0,05)$ dibandingkan So namun berbeda tidak nyata dengan perlakuan dosis 15 ton $\mathrm{ha}^{-1}(\mathrm{~S} 1)$. Pemberian pupuk kotoran sapi dapat memperbaiki dan meningkatkan kandungan unsur hara tanah sehingga mampu meningkatkan pertumbuhan rumput Setaria splendida Stapf dengan meningkatnya jumlah daun dan jumlah anakan. Eriosthafilla et al. (2014) menyatakan pupuk kandang sapi juga meningkatkan kemampuan tanah untuk menyimpan air yang nantinya berfungsi untuk mineralisasi bahan organik menjadi hara yang dapat dimanfaatkan langsung oleh tanaman selama masa pertumbuhannya.

Perlakuan pemberian pupuk kotoran sapi terhadap tinggi tanaman menunjukkan perbedaan tidak nyata $(\mathrm{P}>0,05)$ tetapi ada kecenderungan tertinggi pada perlakuan S2 dibandingkan dengan So dan S1. Hal ini menunjukkan bahwa pada pertumbuhan awal, rumput lebih berperan pada perkembangan daun dan anakan. Disamping itu rumput Setaria splendida Stapf mendapatkan radiasi sinar matahari yang sama sehingga tidak berpengaruh terhadap tinggi tanaman.

Hasil analisis terhadap variabel hasil rumput Setaria splendida Stapf menunjukkan bahwa pemberian perlakuan pupuk kotoran sapi S1 dan S2 terhadap berat kering daun, berat kering batang, berat kering akar, dan berat kering total hijauan menunjukkan perbedaan yang nyata $(\mathrm{P}<0,05)$ dibandingkan dengan perlakuan So. Hal ini juga dipengaruhi oleh meningkatnya jumlah daun dan jumlah anakan, sehingga kemampuan untuk melakukan fotosintesis lebih besar jika dibandingkan dengan perlakuan So sehingga berat kering daun, berat kering batang dan berat kering total hijauan mengalami peningkatan. Berat kering akar juga mengalami peningkatan sehingga mampu memberikan pertumbuhan dan hasil lebih baik pada bagian tanaman diatas tanah.

Nisbah berat kering daun dengan berat kering
Tabel 1. Pertumbuhan Rumput Setaria splendida Stapf yang Dipupuk dengan Pupuk Kotoran Sapi dan Biourin dengan Dosis Berbeda

\begin{tabular}{|c|c|c|c|c|c|c|c|}
\hline \multirow{2}{*}{ Variabel } & \multirow{2}{*}{$\begin{array}{c}\text { Ko- } \\
\text { toran } \\
\text { Sapi }^{1)} \\
\end{array}$} & \multicolumn{4}{|c|}{ Biourin²) } & \multirow{2}{*}{ Rataan } & \multirow{2}{*}{ SEM3） } \\
\hline & & Uo & U1 & U2 & $\mathrm{U}_{3}$ & & \\
\hline \multirow{4}{*}{$\begin{array}{l}\text { Tinggi } \\
\text { tanaman } \\
(\mathrm{cm})\end{array}$} & So & 26,50 & 31,50 & 30,17 & 28,33 & $29,13^{A}$ & 1,71 \\
\hline & S1 & 27,83 & 31,33 & 32,33 & 31,00 & $30,63^{A}$ & \\
\hline & S2 & 32,83 & 31,33 & 28,83 & 29,83 & $30,71^{A}$ & \\
\hline & Rataan & $29,06^{a}$ & $31,39^{a}$ & $30,44^{\mathrm{a}}$ & $29,20^{\mathrm{a}}$ & & \\
\hline \multirow{4}{*}{$\begin{array}{l}\text { Jumlah } \\
\text { daun } \\
\text { (helai) }\end{array}$} & So & 25,33 & 31,67 & 36,67 & 32,33 & $31,50^{B}$ & 8,05 \\
\hline & S1 & 45,00 & 41,67 & 42,33 & 43,33 & $43,08^{\mathrm{AB}}$ & \\
\hline & $\mathrm{S} 2$ & 46,67 & 40,00 & 54,00 & 60,00 & $50,17^{\mathrm{A}}$ & \\
\hline & Rataan & $39, \mathrm{oO}^{\mathrm{a}}$ & $37,78^{\mathrm{a}}$ & $44,33^{\mathrm{a}}$ & $45,22^{\mathrm{a}}$ & & \\
\hline \multirow{4}{*}{$\begin{array}{l}\text { Jumlah } \\
\text { anakan } \\
\text { (anakan) }\end{array}$} & So & 3,00 & 4,00 & 4,60 & 4,60 & $4,08^{B}$ & 1,83 \\
\hline & S1 & 6,33 & 5,6 & 6,6 & 7,00 & $6,42^{\mathrm{AB}}$ & \\
\hline & S2 & 8,33 & 5,67 & 8,33 & 10.00 & $8,08^{\mathrm{A}}$ & \\
\hline & Rataan & $5,89^{\mathrm{a}}$ & $5,11^{\mathrm{a}}$ & $6,56^{\mathrm{a}}$ & $7,22^{\mathrm{a}}$ & & \\
\hline
\end{tabular}

Keterangan:

1) $\mathrm{SO}=0$ ton ha-1, S1 $=15$ ton ha-1, S2 $=30$ ton ha- $\mathrm{ha}^{-1}$

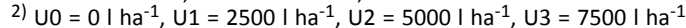

3) SEM = Standard Error of the Treatment Means

4) Nilai dengan huruf kapital yang sama pada satu kolom dan huruf kecil yang sama pada satu baris menunjukkan tidak berbeda nyata $(P>0,05)$

Tabel 2. Hasil Rumput Setaria splendida Stapf yang Dipupuk dengan Pupuk Kotoran Sapi dan Biourin dengan Dosis Berbeda

\begin{tabular}{|c|c|c|c|c|c|c|c|}
\hline \multirow{2}{*}{ Variabel } & \multirow{2}{*}{$\begin{array}{l}\text { Ko- } \\
\text { toran } \\
\text { Sapi }^{11}\end{array}$} & \multicolumn{4}{|c|}{ Biourin $^{2)}$} & \multirow{2}{*}{ Rataan } & \multirow{2}{*}{ SEM 3 ) } \\
\hline & & Uo & U1 & U2 & $\mathrm{U}_{3}$ & & \\
\hline \multirow{4}{*}{$\begin{array}{c}\text { Berat } \\
\text { kering } \\
\text { daun (g) }\end{array}$} & So & 5,00 & 5,90 & 7,33 & 6,90 & $6,28^{\mathrm{B}}$ & \\
\hline & S1 & 8,17 & 9,23 & 8,43 & 7,70 & $8,38^{\mathrm{AB}}$ & 1,29 \\
\hline & S2 & 9,87 & 8,27 & 9,37 & 9,47 & $9,24^{\mathrm{A}}$ & \\
\hline & Rataan & $7,68^{a}$ & $7,80^{\mathrm{a}}$ & $8,38^{a}$ & $8,02^{\mathrm{a}}$ & & \\
\hline \multirow{4}{*}{$\begin{array}{c}\text { Berat } \\
\text { kering } \\
\text { batang } \\
(\mathrm{g})\end{array}$} & So & 4,10 & 4,47 & 5,77 & 5,20 & $4,88^{\mathrm{B}}$ & 0,88 \\
\hline & S1 & 6,07 & 8,85 & 6,60 & 7,00 & $7,13^{\mathrm{A}}$ & \\
\hline & S2 & 8,2 & 7,23 & 7,83 & 7,57 & $7,30^{\mathrm{A}}$ & \\
\hline & Rataan & $6,14^{\mathrm{a}}$ & $6,85^{\mathrm{a}}$ & $6,73 a$ & $6,59 a$ & & \\
\hline \multirow{4}{*}{$\begin{array}{l}\text { Berat } \\
\text { kering } \\
\text { total } \\
\text { hijauan } \\
\text { (g) }\end{array}$} & So & 9,10 & 10,37 & 13,10 & 12,10 & $11,17^{\mathrm{B}}$ & 2,11 \\
\hline & S1 & 14,23 & 15,20 & 15,03 & 14,70 & $14,79^{\mathrm{A}}$ & \\
\hline & $\mathrm{S} 2$ & 18,13 & 15,50 & 17,20 & 17,03 & $16,97^{\mathrm{A}}$ & \\
\hline & Rataan & $13,82^{\mathrm{a}}$ & $13,69^{a}$ & $15,11^{\mathrm{a}}$ & $14,61^{a}$ & & \\
\hline \multirow{4}{*}{$\begin{array}{c}\text { Berat } \\
\text { kering } \\
\operatorname{akar}(g)\end{array}$} & So & 7,27 & 6,50 & 7,80 & 7,33 & $7,23^{\mathrm{B}}$ & 1,10 \\
\hline & S1 & 9,50 & 11,40 & 8,97 & 15,77 & $10,90^{A}$ & \\
\hline & $\mathrm{S} 2$ & 12,60 & 11,03 & 9,33 & 10,23 & $10,80^{A}$ & \\
\hline & Rataan & $9,79^{\mathrm{a}}$ & $9,64^{\mathrm{a}}$ & $8,70^{\mathrm{a}}$ & $11,11^{\mathrm{a}}$ & & \\
\hline
\end{tabular}

Keterangan:

1) $\mathrm{S} 0=0$ ton ha-1, S1 $=15$ ton ha-1, S2 $=30$ ton ha-1

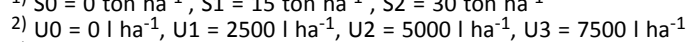

2) $\mathrm{UO}=0 \mathrm{I} \mathrm{ha}^{-1}, \mathrm{U} 1=2500 \mathrm{I} \mathrm{ha}-1, \mathrm{U} 2=5000 \mathrm{I} \mathrm{ha}$
3) $\mathrm{SEM}=$ Standard Error of the Treatment Means

4) Nilai dengan huruf kapital yang sama pada satu kolom dan huruf kecil yang sama pada satu baris menunjukkan tidak berbeda nyata $(P>0,05)$

batang dan nisbah berat kering total hijauan dengan berat kering akar rumput Setaria splendida Stapf menunjukkan pengaruh tidak nyata $(\mathrm{P}>0,05)$. Semakin 
besar berat kering batang maka nisbah berat kering daun dengan berat kering batang menjadi semakin kecil, sehingga menghasilkan rataan yang paling tinggi pada perlakuan So pada variabel nisbah berat kering daun dengan berat kering batang. Semakin tinggi nilai nisbah berat kering daun dengan berat kering batang dan nisbah berat kering total hijauan dengan berat kering akar semakin baik kualitas rumput Setaria splendida Stapf.

\section{Biourin}

Hasil analisis pertumbuhan rumput Setaria splendida Stapf pada tinggi tanaman, jumlah daun dan jumlah anakan menunjukkan tidak berbeda nyata $(\mathrm{P}>0,05)$. Pemberian biourin belum memberikan pengaruh terhadap pertumbuhan rumput Setaria splendida Stapf. Hal ini kemungkinan karena waktu pemberian pupuk biourin kurang tepat. Pemberian biourin dilakukan bertahap yaitu dua minggu setelah penanaman dan dua minggu setelah pemberian pertama sehingga kemungkinan biourin belum dapat dimanfaatkan oleh rumput Setaria splendida Stapf walaupun pupuk biourin tergolong pupuk cair yang lebih mudah diserap oleh akar tumbuhan. Dosis biourin yang diberikan belum mampu mencukupi kebutuhan nitrogen yang diperlukan oleh rumput Setaria splendida Stapf. Menurut Suarna et al. (2019) fungsi nitrogen adalah memperbaiki pertumbuhan vegetatif membentuk protein dan meningkatkan hijau daun pada tumbuhan.

Pada berat kering daun, berat kering batang, berat kering total hijauan dan berat kering akar menunjukkan tidak berbeda nyata $(\mathrm{P}>0,05)$. Peningkatan pemberian dosis biourin sampai dengan $7500 \mathrm{l} \mathrm{ha}^{-1}$ belum memberikan respon terhadap pertumbuhan dan hasil rumput Setaria splendida Stapf. Nuriyasa et al. (2012) mendapatkan dosis $75000 \mathrm{l} \mathrm{ha}^{-1}$ menghasilkan pertumbuhan dan hasil tertinggi. Semakin tinggi dosis biourin yang diberikan maka pertumbuhan dan hasil hijauan akan meningkat.

Karakteristik tumbuh rumput Setaria splendida Stapf menunjukkan bahwa pemberian perlakuan pupuk biourin $\mathrm{U}_{3}$ terhadap nisbah berat kering daun dengan berat kering batang dan nisbah berat kering total hijauan dengan berat kering akar, menunjukkan perbedaan yang tidak nyata $(\mathrm{P}>0,05)$. Sesuai dengan pendapat Mendra (1991) yang menyatakan bahwa secara morfologi, pertumbuhan batang rumput lebih tinggi sehingga porsi pemanfaatan hara lebih diprioritaskan pada pertumbuhan di atas tanah dibandingkan dengan pertumbuhan di bawah tanah (akar). Hal ini disebabkan karena, semakin tinggi unsur hara tersedia bagi tanaman menyebabkan pertumbuhan dan produktivitas meningkat

\section{SIMPULAN}

Berdasarkan hasil penelitian dapat disimpulkan bahwa rumput Setaria splendida Stapf yang diberi pupuk kotoran sapi dengan dosis sampai 15 ton ha $\mathrm{h}^{-1}$ memberikan pertumbuhan dan hasil terbaik, pupuk biourin sampai dosis $7500 \mathrm{l} \mathrm{ha}^{-1}$ tidak berpengaruh terhadap pertumbuhan dan hasil rumput serta tidak terjadi interaksi antara pupuk kotoran sapi dengan biourin terhadap pertumbuhan dan hasil rumput Setaria splendida Stapf.

\section{DAFTAR PUSTAKA}

Adijaya, I N. 2009. Potensi limbah sapi pada integrasi tanaman pakan ternak. Bulletin Teknologi dan Informasi Pertanian Edisi 21, Tahun VII, September 2009. Denpasar, Balai Pengkajian Teknologi Pertanian Bali.

Arnawa, I W. 2014. Pertumbuhan dan produksi rumput benggala (Panicum maximum $\mathrm{cv}$. Trichoglume) yang diberi pupuk organik dengan level berbeda. Peternakan Tropika. Vol. 2 No. 2. Hal. 225-239

Tabel 3. Karateristik Tumbuh Rumput Setaria splendida Stapf yang Dipupuk dengan Pupuk Kotoran Sapi dan Biourin dengan Dosis Berbeda

\begin{tabular}{|c|c|c|c|c|c|c|c|}
\hline \multirow{2}{*}{ Variabel } & \multirow{2}{*}{$\begin{array}{l}\text { Kotoran } \\
\text { Sapi }^{1)}\end{array}$} & \multicolumn{4}{|c|}{ Biourin $^{2)}$} & \multirow{2}{*}{ Rataan } & \multirow{2}{*}{ SEM 3 ) } \\
\hline & & Uo & U1 & U2 & $\mathrm{U}_{3}$ & & \\
\hline \multirow{4}{*}{$\begin{array}{c}\text { Nisbah berat kering daun dengan } \\
\text { berat kering batang }\end{array}$} & So & 1,20 & 1,26 & 1,27 & 1,32 & $1,26^{\mathrm{A}}$ & \multirow[t]{3}{*}{0,09} \\
\hline & $\mathrm{S} 1$ & 1,35 & 1,03 & 1,24 & 1,11 & $1,18^{\mathrm{A}}$ & \\
\hline & S2 & 1,18 & 1,15 & 1,21 & 1,25 & $1,20^{\mathrm{A}}$ & \\
\hline & Rataan & $1,24^{\mathrm{a}}$ & $1,15^{\mathrm{a}}$ & $1,24^{\mathrm{a}}$ & $1,23^{\mathrm{a}}$ & & \\
\hline \multirow{4}{*}{$\begin{array}{l}\text { Nisbah berat kering total hijauan } \\
\text { dengan berat kering akar }\end{array}$} & So & 1,27 & 1,53 & 1,68 & 1,71 & $1,55^{\mathrm{A}}$ & \multirow[t]{3}{*}{0,15} \\
\hline & $\mathrm{S} 1$ & 1,51 & 1,59 & 1,65 & 0,98 & $1,43^{\mathrm{A}}$ & \\
\hline & $\mathrm{S} 2$ & 1,43 & 1,43 & 1,84 & 1,67 & $1,59^{\mathrm{A}}$ & \\
\hline & Rataan & $1,40^{\mathrm{a}}$ & $1,52^{\mathrm{a}}$ & $1,72^{\mathrm{a}}$ & $1,45^{\mathrm{a}}$ & & \\
\hline
\end{tabular}

1) $\mathrm{SO}=0$ ton ha-1, $\mathrm{S} 1=15$ ton ha-1, $\mathrm{S} 2=30$ ton ha ha-1

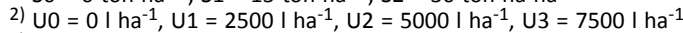

3) SEM = Standard Error of theTreatment Means

4) Nilai dengan huruf kapital yang sama pada satu kolom dan huruf kecil yang sama pada satu baris menunjukkan tidak berbeda nyata $(P>0,05)$ 
Eriosthafilla W., Sudiarso, dan S. Roedy. 2014 Pengaruh Pemberian Air dan Pupuk Kandang Sapi terhadap Pertumbuhan dan Hasil Tanaman Jagung Manis (Zea mays saccharata Sturt L.). Jurusan Budidaya Pertanian, Fakultas Pertanian, Universitas Brawijaya. Malang.

Indranada. 1985. Pengelolaan Kesuburan Tanah. Bina Aksara. Jakarta.

Mcllroy R. J. 1976. Pengantar Padang Rumut Tropika. Diterjemahkan Fakultas Peternakan. Institut Pertanian Bogor. Bogor.

Mendra, K, 1991. Evaluasi sifat- sifat pertumbuhan dan produksi rumput unggul untuk hijauan makanan ternak. Laporan Penelitian. Fakultas Peternakan, Universitas Udayana, Denpasar.

Nurhayati, H., Nyakpa, M. Y., Lubis, A. M., Nugroho, S. G., Saul, R., Amin, D. M., Go Ban Hong, H. H. 1986. Dasar Dasar Ilmu Tanah. Lampung: Universitas Lampung.
Nuriyasa, I M., N. N. Candraasih K., A. A. A. S. Trisnadewi, E. Puspani, W. Wirawan. 2012. Peningkatan Hasil Rumput Gajah (Pennisetum purpureum) dan Rumput Setaria (Setaria splendida Stapf) melalui Pemupukan Biourin. Pastura. v. 2, n. 2ISSN 2549-8444. Sumber: https://ojs.unud.ac.id/index.php/pastura/ article/view/9029 doi:https://doi.org/10.24843/ Pastura.2013.v02.io2.po9.

Suarna, W., N. N. Suryani., dan K. M. Budiasa. 2019. Biodiversitas Tumbuhan Pakan Ternak. Prasasti. Bali. 92 halaman.

Surriadikarta, D. A., dan R.D.M. Simanungkalit. 2006.Pupuk Organik dan Pupuk Hayati. Jawa Barat: Balai Besar Penelitian dan Pengembangan Sumberdaya Lahan Pertanian. Hal 2. ISBN 978979- 9474-57-5.

Susetyo.S., I. Kismono, dan B. Soewandi. 1980. Hijauan Makanan Ternak. Direktorat Jenderal Peternakan. Departemen Pertanian. Jakarta. 